\title{
Features of the Development of Processing Flow Sheets of Carbon-Gold-Sulphide Ores
}

Victor N. Kovalev*, Valeriy V. Golikov and Nikolay V. Rylov

Polymetal Engineering JSC

2 Narodnogo Opolcheniya, St. Petersburg, 198216, Russia

Received 28.02.2017, received in revised form 12.03.2017, accepted 23.03.2017

Designers often focus on metallurgical aspects in the development of technologies for processing of refractory gold-ores, although the choice of an efficient mineral processing technology can greatly facilitate the work of metallurgists and reduce the cost of concentrates processing. Schemes enrichment of carbon-gold-ores have some specificity and only it understanding ensures high technical and economic effect of the processing of this material.

Keywords: gold, organic carbon, refractory ores, mineral processing, carbon flotation, desliming, depression, selection.

DOI: $10.17516 / 1998-2836-0010$.

(C) Siberian Federal University. All rights reserved

* Corresponding author E-mail address: KovalevVN@polymetal.ru 


\title{
Особенности разработки технологических схем обогащения углеродсодержащих золотосульфидных руд
}

\author{
В.Н. Ковалев, В.В. Голиков, Н.В. Рылов \\ АO «Полиметалл Инжиниринг» \\ Россия, 198216, Санкт-Петербург, пр. Народного Ополчения, 2
}

При разработке технологии переработки упорных золотосульфидных руд часто основное внимание уделяется металлургическому переделу, хотя выбор эффективной технологии обогащения может существенно облегчить работу металлургов и снизить затраты на переработку концентратов. Схемы обогащения углеродсодержащих золотосульфидных руд имеют выраженную специфику, понимание которой позволяет обеспечить высокие техникоэкономические показатели переработки этого сырья.

Ключевые слова: золото, органический углерод, упорные руды, обогащение, углеродная флотация, обесшламливание, депрессия, селекиия.

\section{Введение}

С учетом истощения минерально-сырьевой базы наиболее перспективными для разработки на территории России являются крупные месторождения золота черносланцевого и карлинского типов, переработка которых осложнена тонкой вкрапленностью золота в сульфидные минералы и присутствием сорбционно активного рассеянного углеродистого вещества (РУВ). К так называемым золотосульфидным рудам «двойной упорности» относятся крупнейшие отечественные и зарубежные месторождения (табл. 1), в том числе «Наталкинское», «Олимпиадинское», «Нежданинское», «Майское», «Бакырчик» и др. [1, 2]. На долю таких месторождений по разным оценкам приходится до 20 \% мировых запасов золота.

При разработке технологии переработки упорных руд часто основное внимание уделяется металлургическому переделу, хотя выбор эффективной технологии обогащения может существенно облегчить работу металлургов и значительно улучшить экономику всего проекта. На основе опыта АО «Полиметалл Инжиниринг» по разработке комплексных технологий переработки руд «двойной упорности» (месторождения «Майское», «Бакырчик», «Нежданинское») можно заключить, что технологические схемы обогащения углеродсодержащих золотосульфидных руд имеют выраженную специфику, без понимания которой невозможно обеспечить высокие технико-экономические показатели переработки этого сложного сырья.

Разработка технологии обогащения не содержащих РУВ упорных золотосульфидных руд часто представляет собой достаточно тривиальную задачу, решение которой обычно сводится к выбору между классическими вариантами схем сульфидной флотации, иногда в сочетании с гравитационным переделом [3]. Наличие в руде углеродистого вещества, в особенности в виде сорбционно активных органических соединений, содержание которых может достигать 2-3 \%, существенно усложняет выбор эффективной технологии переработки (табл. 2). РУВ при измельчении ошламовывается и в дальнейшем негативно влияет на эксплуатационные и техно- 
Victor N. Kovalev, Valeriy V. Golikov... Features of the Development of Processing Flow Sheets of Carbon-Gold-Sulphide...

Таблица 1. Наиболее крупные месторождения золотосульфидных руд «двойной упорности»

\begin{tabular}{|l|l|}
\hline \multicolumn{1}{|c|}{ Тип месторождения } & \multicolumn{1}{|c|}{ Наиболее крупные месторождения } \\
\hline $\begin{array}{l}\text { Золото-кварцево-сульфидные руды в } \\
\text { углеродсодержащих песчано-сланцевых толщах } \\
\text { (черные сланцы) }\end{array}$ & $\begin{array}{l}\text { Телфер (Австралия), Мурунтау (Узбекистан), } \\
\text { Бакырчик (Казахстан), Наталкинское, } \\
\text { Нежданинское, Майское, Вернинское, Маломыр } \\
\text { (Россия) }\end{array}$ \\
\hline $\begin{array}{l}\text { Месторождения карлинского типа (золото- } \\
\text { полисульфидные джаспероидные руды в } \\
\text { терригенно-карбонатных толщах) }\end{array}$ & $\begin{array}{l}\text { Карлин, Голдстрайк (США), Цзиньфын (Китай), } \\
\text { Паракуту (Бразилия), Олимпиадинское, } \\
\text { Куранахское (Россия) }\end{array}$ \\
\hline
\end{tabular}

Таблица 2. Особенности технологических схем переработки упорных золотосульфидных руд

\begin{tabular}{|c|c|}
\hline Причина упорности & Влияние на технологию переработки \\
\hline $\begin{array}{l}\text { Тонкая ассоциация } \\
\text { золота с сульфидными } \\
\text { минералами (первая } \\
\text { степень упорности) }\end{array}$ & $\begin{array}{l}\text { Низкая эффективность прямого цианирования золота. Необходимость } \\
\text { применения дорогостоящих технологических операций для вскрытия золота } \\
\text { перед цианированием (BIOX, POX, Albion и др.) }\end{array}$ \\
\hline \multirow{5}{*}{$\begin{array}{l}\text { Тонкая ассоциация } \\
\text { золота с сульфидными } \\
\text { минералами и наличие } \\
\text { в руде сорбционно } \\
\text { активного РУВ } \\
\text { («двойная упорность») }\end{array}$} & $\begin{array}{l}\text { Ухудшение селективности процесса флотации (повышение выхода и } \\
\text { снижение качества золотосульфидных концентратов) }\end{array}$ \\
\hline & Загрязнение золотосульфидных концентратов РУВ \\
\hline & Повышение расхода флотационных реагентов \\
\hline & $\begin{array}{l}\text { Ухудшение показателей обезвоживания продуктов обогащения и повышение } \\
\text { стоимости реализации этих переделов }\end{array}$ \\
\hline & $\begin{array}{l}\text { Ухудшение технологических показателей гидрометаллургической } \\
\text { переработки флотоконцентратов либо заметное удорожание этих операций }\end{array}$ \\
\hline
\end{tabular}

логические показатели работы флотационного передела, повышая расходы реагентов и снижая селективность процесса в целом. Концентрат загрязняется углистыми включениями, доля которых может превышать $10 \%$ [2].

Вещественный состав золотосодержащих концентратов, полученных при обогащении руд «двойной упорности», оказывает критическое влияние на технологические и экономические показатели работы гидрометаллургического передела. К примеру, экспериментально установлено [4], что в большинстве случаев удается предсказать результаты переработки таких концентратов методом автоклавного окисления с последующим сорбционным цианированием (POX-CIL), пользуясь простым эмпирическим соотношением $\mathrm{Au} / \mathrm{C}_{\text {орг }}$ (отношение содержания золота в перерабатываемом материале, выраженное в граммах на тонну, к содержанию органической части РУВ, выраженному в килограммах на тонну). Так, для флотационных концен-

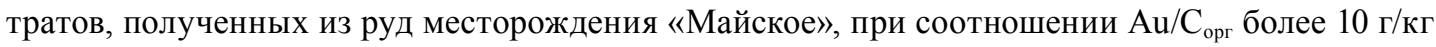
извлечение золота по технологии POX-CIL (температура в автоклаве $200{ }^{\circ} \mathrm{C}$, содержание хлоридных анионов в жидкой фазе пульпы до 10 мг/л) превышает 90 \%. В случае уменьшения этого соотношения до 2,5 г/кг извлечение золота снижается до 55-70 \%.

При вовлечении в переработку руд «двойной упорности» обогатительный передел должен рассматриваться, в первую очередь, как инструмент оптимизации вещественного состава ис- 
ходного сырья перед извлечением золота металлургическими методами. В данном контексте основной задачей реализации обогатительных операций является снижение содержания РУВ в концентрате при одновременном повышении содержания золота в этом продукте. Оптимальный выход концентрата определяется на основе технико-экономических расчетов, учитывающих стоимость обогащения руды, характер зависимости извлечения золота в концентрат от выхода, влияние вещественного состава на себестоимость и показатели металлургической переработки концентрата, логистические расходы и другие параметры. Следует отметить, что выбор оптимальной технологии обогащения сложного рудного сырья всегда должен рассматриваться как итерационный процесс, поскольку результаты металлургических исследований и экономических расчетов зачастую вынуждают корректировать исходные установки для поиска максимума доходности по технологии в целом.

Оптимизация обогатительного передела в более узком смысле сводится к рассмотрению в рамках общей флотационной или гравитационно-флотационной схемы ряда дополнительных технологических операций, нацеленных на снижение содержания РУВ в товарных концентратах (обезуглероживание) и/или расширение товарной диверсификации (выпуск селективных продуктов обогащения).

\section{Обезуглероживание}

Наиболее перспективным является ступенчатый подход к вопросу снижения содержания РУВ в товарных продуктах обогатительного передела - в «голове» процесса обогащения реализуется самостоятельная операция обезуглероживания, а далее на флотационном переделе применяются высокоэффективные депрессоры РУВ. Указанные мероприятия позволяют снизить содержание органического углерода во флотационном концентрате в несколько раз и улучшить другие технологические показатели.

Основная задача, решаемая самостоятельной операцией обезуглероживания, - максимизация извлечения органического углерода в отвальный углеродный продукт при минимизации потерь ценных компонентов с этим продуктом. Для различных руд оптимальное соотношение извлечения органического углерода и потерь ценного компонента определяется, в первую очередь, их минералогическими особенностями и может подбираться только опытным путем. Для некоторых руд включение отдельной операции обезуглероживания в схему обогащения оказывается нежелательным, так как прирост извлечения ценного компонента в товарный концентрат или повышение его качества не компенсирует потерь с отвальным углеродным продуктом. В качестве операций предварительного обезуглероживания руды перед сульфидной флотацией могут рассматриваться обесшламливание и углеродная флотация, в том числе возможна их последовательная реализация.

\section{Обесшламливание}

РУВ склонно к ошламованию в процессе измельчения, и даже при достаточно грубом помоле его существенная часть концентрируется в шламовых классах крупности. По результатам исследований на различных рудах уже в дробленом до крупности $-5+0$ мм (15\% класса $-0,071+0$ мм) материале с классом -0,025+0 мм ассоциировано более $10 \%$ органического углерода, при измельчении до крупности $40 \%$ класса $-0,071+0$ мм это значение увеличивается до 
30 \%, при измельчении до крупности 80 \% класса -0,071+0 мм - превышает 60 \%. Такое поведение РУВ делает возможным реализацию обезуглероживания за счет дешламации в гидроциклонах.

При измельчении руды до 80 \% класса -0,071+0 мм дешламация по классу 10 мкм позволяет перевести в хвосты до 40 \% РУВ, но принципиальным вопросом в этом случае становится величина потерь золота со сбрасываемыми шламами. Золотосодержащие сульфиды, в особенности арсенопирит, также склонны к ошламованию; соответственно, часть золота неизбежно будет теряться со сливом гидроциклонов. Именно высокие потери золота со сбросным продуктом не позволили рекомендовать обесшламливание для реализации в схемах переработки руд месторождений «Майское» и «Бакырчик».

В то же время даже когда потери золота с отвальным продуктом приемлемы (к примеру, для руд Нежданинского месторождения), необходимо весьма консервативно оценивать возможные риски. Результаты дешламации с трудом поддаются контролю и практически полностью зависят от поведения конкретной руды в цикле измельчения. С учетом того, что технологические свойства руды могут заметно меняться даже в пределах одного рудного тела, нельзя ожидать от дешламации устойчивых показателей на всем периоде эксплуатации обогатительного предприятия.

\section{Углеродная флотация}

В сравнении с дешламацией углеродная флотация является более гибкой операцией. РУВ, обладающее природной гидрофобностью, хорошо флотируется с применением одного только вспенивателя, причем использование дополнительных реагентов зачастую оказывается малоэффективным либо ухудшает показатели последующей сульфидной флотации. На основании результатов длительных технологических исследований углеродная флотация включена, к примеру, в схему обогащения руд месторождения «Бакырчик». Допустимыми приняты потери золота с углеродным продуктом до 2,0 \% от руды при извлечении в него РУВ на уровне 30-40 \%. Показано, что удаление в «голове» процесса наиболее активной части органического углерода в сочетании с применением депрессора РУВ в сульфидном флотационном цикле позволяет в 2-3 раза уменьшить содержание РУВ в золотосульфидном концентрате и снизить расход дорогостоящих флотореагентов. В то же время реализация углеродной флотации в схеме обогащения руд месторождения «Майское» в силу их минералогических особенностей признана нецелесообразной, так как влечет чрезмерное увеличение потерь золота (рис. 1).

Главной причиной потерь золота с концентратом углеродной флотации является низкая селективность обогащения шламовых классов крупности. Показано, что именно со шламами ассоциировано практически все золото, переходящее в отвальный углеродный продукт (табл. 3). В большинстве случаев повысить селективность процесса подбором реагентного режима не удается - использование различных вспенивателей (Т-92, ПМ-2, сосновое масло, МИБК и др.) дает схожие результаты. По-видимому, свойства вспенивателя могут ограниченно влиять на время удержания в пенном продукте механически вынесенных в нее переизмельченных сульфидов, но не на селективность обогащения ошламованных частиц.

$$
-103-
$$




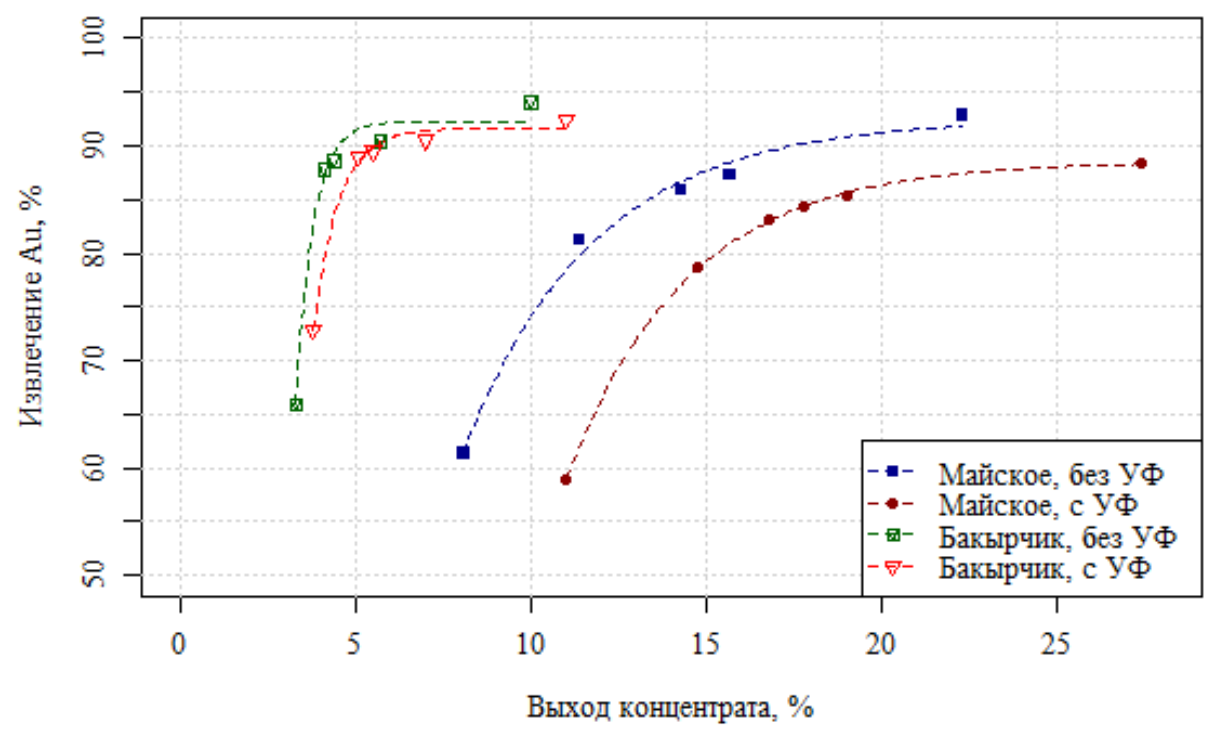

Рис. 1. Влияние углеродной флотации на зависимость извлечения золота в концентрат от выхода этого продукта при обогащении руд месторождений «Майское» и «Бакырчик»

Таблица 3. Ситовой анализ концентрата углеродной флотации с распределением основных элементов по классам крупности

\begin{tabular}{|c|c|c|c|c|c|c|c|}
\hline \multirow{2}{*}{$\begin{array}{c}\text { Класс } \\
\text { крупности, } \\
\text { мм }\end{array}$} & \multirow{2}{*}{ Выход, \% } & \multicolumn{3}{|c|}{ Содержание, г/т, \% } & \multicolumn{3}{|c|}{ Распределение, \% } \\
\cline { 3 - 8 } & & $\mathrm{Au}$ & $\mathrm{S}_{\text {сульфид }}$ & $\mathrm{C}_{\text {орг }}$ & $\mathrm{Au}$ & $\mathrm{S}_{\text {сульфид }}$ & $\mathrm{C}_{\text {орг }}$ \\
\hline$+0,025$ & 8,30 & 1,95 & 0,84 & 38,40 & 3,31 & 8,12 & 15,13 \\
\hline$-0,025$ & 91,70 & 5,15 & 0,86 & 19,50 & 96,69 & 91,88 & 84,87 \\
\hline Всего & 100,00 & 4,88 & 0,86 & 21,07 & 100,00 & 100,00 & 100,00 \\
\hline
\end{tabular}

Перспективным направлением улучшения показателей углеродной флотации представляется внедрение современного флотационного оборудования, ориентированного на извлечение ультратонких частиц, в сочетании с подбором оптимальной тонины помола перед этой операцией. К примеру, у компании Glencore Technology есть положительный опыт применения колонных флотомашин Jameson Cell (JC) в операции предварительной флотации органического углерода на рудниках Ред-Дог (Аляска) [5], Century (Австралия) и Mount Isa (Австралия).

В исследованиях АО «Полиметалл Инжиниринг» [6] для руды месторождения «Бакырчик» рассмотрено влияние на показатели углеродной флотации типа флотомашины и крупности помола (рис. 2). Выполнено сравнение результатов, полученных на механической лабораторной флотомашине при помолах 40 и 80 \% класса $-0,071$ мм, с результатами опыта на материале крупностью 80 \% класса -0,071 мм, проведенного с использованием установки JC.

Лучшие результаты углеродной флотации при тонине помола 80 \% класса -0,071 мм получены на флотомашине $\mathrm{JC}$ - для рабочего диапазона выхода менее 2,5 \% извлечение органи- 


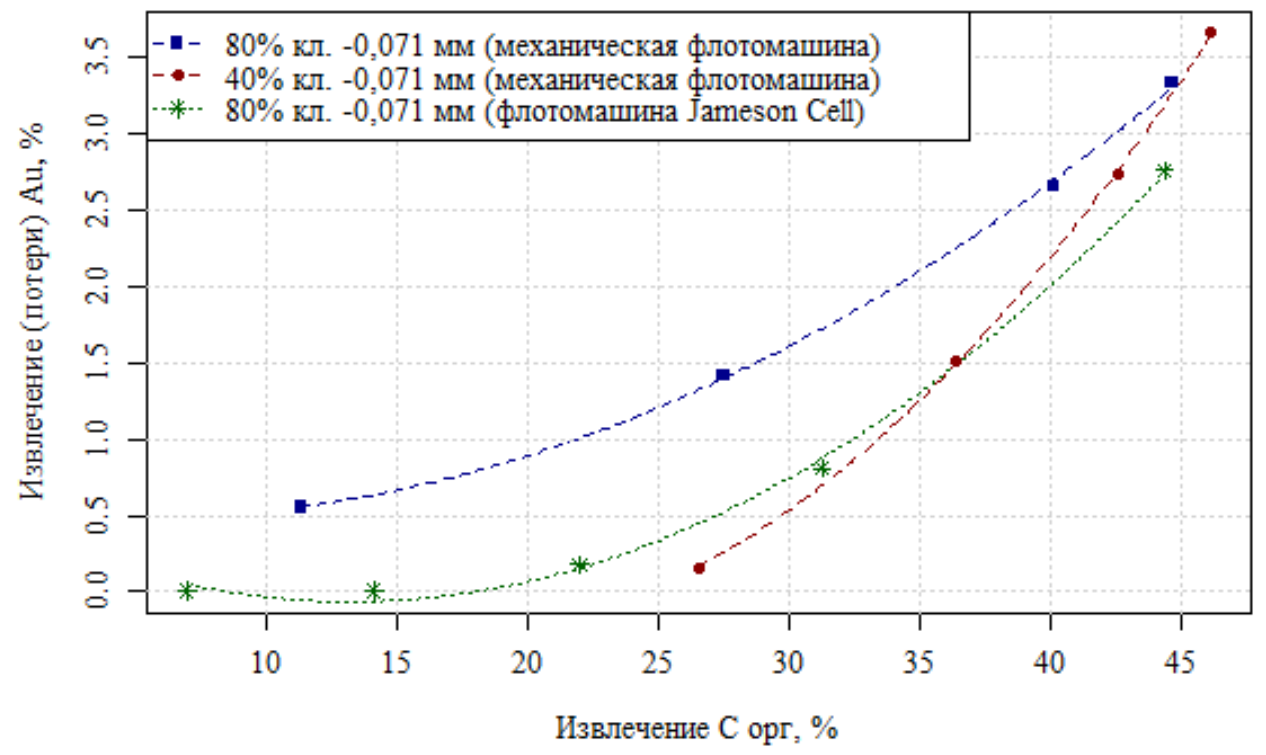

Рис. 2. Зависимости извлечения золота в отвальный углеродный продукт (концентрат углеродной флотации) от извлечения в него органического углерода для различных типов флотомашин и крупности помола (на примере руды месторождения «Бакырчик»)

ческого углерода достигает 40 \% при потерях золота с углеродным продуктом менее $2 \%$. Такой результат, по-видимому, объясняется более высокой эффективностью извлечения тонких классов во флотомашине JC за счет ее конструктивных особенностей. Однако при крупности исходного питания 40 \% класса $-0,071$ мм результаты углеродной флотации в лабораторной механической флотомашине сопоставимы с результатами, полученными при флотации на JC. Улучшение показателей углеродной флотации с применением механических флотомашин при ее реализации на более грубом помоле объясняется снижением количества ошламованных золотосодержащих сульфидов в питании флотационного передела и, соответственно, уменьшением доли сульфидов, механически вынесенных в пену.

Как указывалось выше, реализация обезуглероживания в виде отдельной технологической операции не всегда возможна. В то же время применение селективного депрессора РУВ в операциях сульфидной флотации в большинстве случаев позволяет улучшить технологические показатели обогащения. В качестве перспективных депрессоров могут тестироваться различные химические соединения: водорастворимый нигрозин, технические лигносульфонаты, декстрин и специфические зарубежные реагенты (производители Solvay, BASF, Clariant).

Влияние депрессора РУВ на показатели обогащения, в зависимости от особенностей конкретной руды и технологической схемы ее переработки (наличие/отсутствие самостоятельной операции обезуглероживания), может проявляться по-разному (рис. 3). В одних случаях оно выражается преимущественно в изменении распределения углерода по продуктам флотационного цикла (снижение содержания РУВ в золотосульфидных концентратах) без существенной корректировки зависимости «выход концентрата/извлечение золота» (к примеру, для руд Бакырчика). В других случаях может проявляться значительное влияние на селективность процесса обогащения, к примеру, для руд месторождения «Майское» приме-

$$
-105-
$$




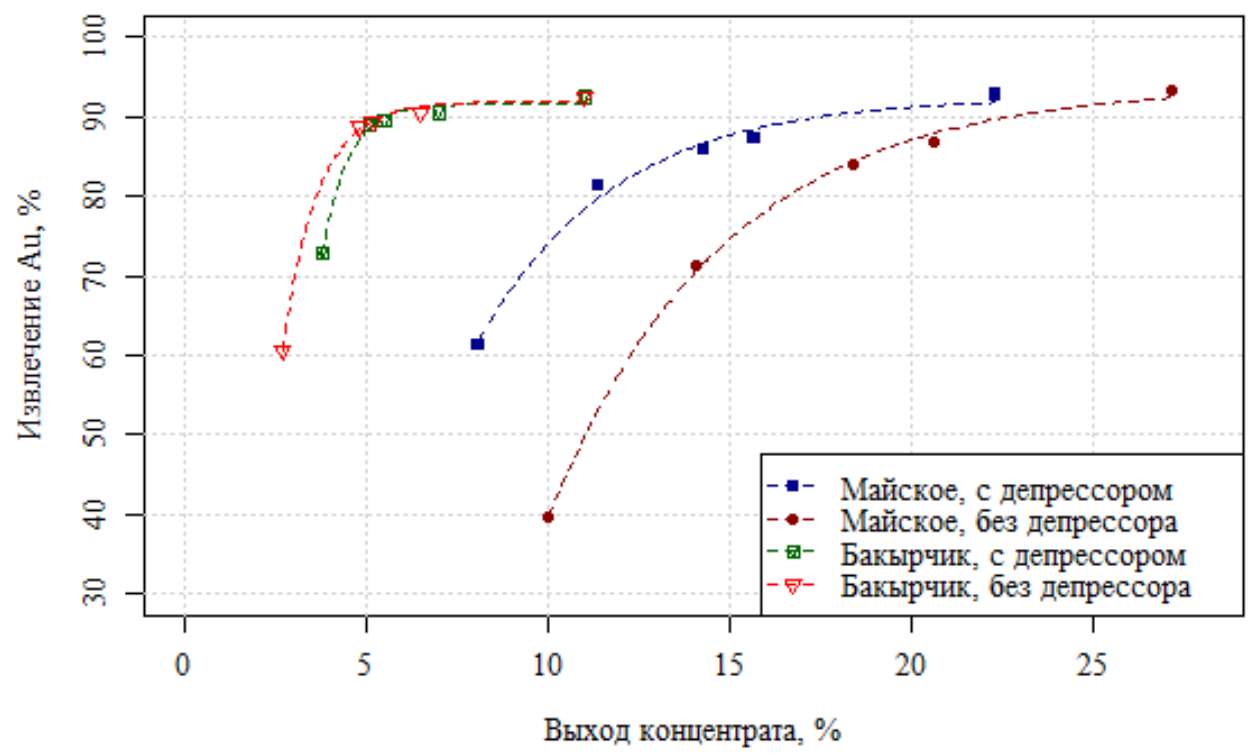

Рис. 3. Влияние депрессора РУВ на зависимости извлечения золота в золотосульфидный концентрат от выхода этого продукта при обогащении руд месторождений «Майское» и «Бакырчик»

нение депрессора РУВ не только позволяет улучшить качество флотоконцентрата, повысив отношение $\mathrm{Au} / \mathrm{C}_{\text {орг }}$, но и снижает выход золотосульфидного продукта при сохранении уровня извлечения в него золота.

\section{Товарная деверсификация}

В наиболее сложных случаях, при высоком исходном содержании РУВ в руде, только за счет описанных выше методов обезуглероживания часто не удается получить золотосульфидные продукты, пригодные для непосредственной переработки стандартными гидрометаллургическими методами. Извлечение золота из концентратных продуктов с низким отношением $\mathrm{Au} / \mathrm{C}_{\text {орг }}$, учитывая специфику отечественного экологического законодательства, требует применения передовых технологических решений, что приводит к заметному росту капитальных и впоследствии эксплуатационных затрат, снижая инвестиционную привлекательность проекта.

Перспективным в этой ситуации может оказаться вариант с расширением номенклатуры выпускаемых товарных продуктов, что в контексте обогащения руд «двойной упорности» подразумевает производство двух типов золотосульфидных концентратов - с высоким и низким содержаниями РУВ. Низкоуглеродистый золотосульфидный концентрат (НУК) пригоден для гидрометаллургической переработки по типовым технологическим схемам с высокой экономической эффективностью, а высокоуглеродистый золотосульфидный концентрат (ВУК), переработка которого требует более сложных технологических решений, с целью снижения капитальных расходов на начальном этапе производства может рассматриваться как продукт для продажи сторонним потребителям.

Производство разнотипных концентратов возможно за счет включения в технологическую схему обогатительного передела операций селекции на основе флотационных либо гравитаци-

$$
-106-
$$


онных методов. Углеродная флотация в широком смысле также операция селекции, на которой выделяется селективный углеродистый концентрат, однако, поскольку этот продукт не является товарным, данная операция рассматривалась в другом разделе. Проблема селективного выделения РУВ из загрязненных им золотосульфидных продуктов на данный момент еще не решена. В рамках рассматриваемого подхода под селекцией понимается выделение преимущественно арсенопиритного концентрата с относительно низким содержанием РУВ и преимущественно пиритного концентрата.

Разделение пирита и арсенопирита во флотационном цикле реализуется типовыми методами [7], при этом за счет высокой конкуренции в начале процесса селекции извлечение органического углерода в арсенопиритный продукт оказывается ниже, чем в пиритный. Кроме того, содержание золота в арсенопирите всегда заметно выше, чем в пирите, поэтому отношение $\mathrm{Au} / \mathrm{C}_{\text {орг }}$ для арсенопиритного продукта оказывается достаточно высоким, чтобы характеризовать его как золотосульфидный продукт, пригодный к переработке по типовым гидрометаллургическим схемам.

Гравитационная селекция основана на различии в плотностях золотосодержащих сульфидов - арсенопирит преимущественно переходит в концентрат гравитационного передела, а основная часть пирита остается в хвостах вместе с РУВ и ошламованными сульфидами [8]. Применением гравитационных методов отношение $\mathrm{Au} / \mathrm{C}_{\text {орг }}$ можно повысить в 10 и более раз.

Операции селекции в зависимости от особенностей конкретной руды могут реализовываться как на исходной руде, так и на конечных продуктах схемы обогащения. Второй вариант делает технологию более гибкой, так как может использоваться опционно. К примеру, в стандартных условиях конечным продуктом передела обогащения руды месторождения «Бакырчик» является коллективный флотационный концентрат с относительно низким отношением $\mathrm{Au} / \mathrm{C}_{\text {орг }}$ В то же время при благоприятной экономической конъюнктуре опционное использование гравитационной селекции позволяет перевести 40 \% золота из этого продукта в низкоуглеродистый золотосульфидный концентрат (табл. 4).

\section{Выводы}

1. Экономическая обоснованность технологических решений и показателей работы обогатительного передела в значительной степени определяет экономическую эффективность всей комплексной технологии переработки руды «двойной упорности». При вовлечении в переработку таких руд обогащение должно рассматриваться, в первую очередь, как инструмент

Таблица 4. Результаты гравитационной селекции золотосульфидного флотационного концентрата из руды месторождения «Бакырчик»

\begin{tabular}{|c|c|c|c|c|c|c|c|c|}
\hline \multirow{2}{*}{ Продукт } & \multirow{2}{*}{ Выход, \% } & \multicolumn{3}{|c|}{ Содержание, г/т, \% } & \multicolumn{3}{|c|}{ Извлечение, \% } & \multirow{2}{*}{$\mathrm{Au} / \mathrm{C}_{\mathrm{opr}}, \Gamma / \kappa \Gamma$} \\
\hline & & $\mathrm{Au}$ & $\mathrm{S}_{\text {сульфид }}$ & $\mathrm{C}_{\text {opr }}$ & $\mathrm{Au}$ & $\mathrm{S}_{\text {сульфид }}$ & $\mathrm{C}_{\text {opr }}$ & \\
\hline Коллективн. к-т & 100,0 & 104,5 & 22,9 & 2,2 & 100,0 & 100,0 & 100,0 & 4,8 \\
\hline НУК & 17,9 & 227,0 & 29,8 & 0,5 & 38,8 & 23,3 & 4,3 & 43,7 \\
\hline ВУК & 82,1 & 77,9 & 21,3 & 2,5 & 61,2 & 76,7 & 95,7 & 3,1 \\
\hline
\end{tabular}


оптимизации вещественного состава исходного сырья перед извлечением золота металлургическими методами.

2. Наиболее эффективен ступенчатый подход при обезуглероживании руд, содержащих РУВ - в «голове» процесса проводят обесшламливание и/или углеродную флотацию, а в последующих операциях применяют высокоэффективные депрессоры органического углерода. Однако даже если реализация отдельной операции обезуглероживания невозможна, применение селективного депрессора РУВ в операциях сульфидной флотации позволяет заметно улучшить технологические показатели обогащения.

3. В сложных случаях, когда не удается получить кондиционный по содержанию РУВ золотосульфидный концентрат, перспективно рассмотреть вариант с расширением номенклатуры выпускаемых товарных продуктов, что в контексте обогащения руд «двойной упорности» подразумевает производство двух типов золотосульфидных концентратов, перерабатываемых впоследствии по различным технологическим схемам - с высоким и низким содержаниями органического углерода. Реализация селекции возможна применением специфических флотационных и/или гравитационных операций на различных этапах обогащения руды.

\section{Список литературы}

1. Меритуков М.А. Золото и природное углеродистое вещчество. М.: Издательский дом «Руда и металлы», 2007. 112 с. [Meretukov M.A. Gold and natural carbon substance. Moscow: Publishing house “Ore and Metals”, 2007. 112 p. (in Russian)]

2. Лодейщиков В.В. Технология извлечения золота и серебра из упорных руд: В 2 т. Иркутск: ОАО «Иргиредмет», 1999. T.1. 342 с. [Lodeischikov V.V The technology of gold and silver recovery from refractory ores: in 2 volumes. Irkutsk: Irgiredmet JSC 1999, Vol. 1. 342 p. (in Russian)]

3. Лодейщиков В.В. Технология извлечения золота и серебра из упорных руд: В 2 т. Иркутск: ОАО «Иргиредмет», 1999. T. 2. 452 с. [Lodeischikov V.V. The technology of gold and silver recovery from refractory ores: in 2 volumes. Irkutsk; Irgiredmet JSC 1999, Vol. 2. 452 p. (in Russian)]

4. Тер-Оганесянц А.К., Ковалев В.Н., Каплан С.Ф., Воробьев-Десятовский Н.В. Влияние температуры, концентрации хлорид-иона и соотношения $\mathrm{Au} / \mathrm{C}_{\text {орг }}$ на извлечение золота из упорных сульфидных концентратов методом автоклавного окисления. XX международная Черняевская конференциия по химии, аналитике и технологии платиновых металлов 2013, 163 c. [Ter-Oganesyants A.K., Kovalev V.N., Kaplan S.F., Vorobiev-Desyatovsky N.V. Influence of temperature, concentration of chloride-ion and the ratio of $\mathrm{Au} / \mathrm{Corg}$ on gold extraction from refractory sulfide concentrates by POX. XX International Chernyayevsky conference on chemistry, analytics and technology of platinum metals 2013. 163 p. (in Russian)]

5. Smith T., Lin D., Lacouture B., Anderson G. Removal of organic carbon with a Jameson Cell at Red Dog Mine, 40th Annual Meeting of the Canadian Mineral Processing. Ontario, Canada, 2015. P. 333-347.

6. Ковалев В.Н., Асанова И.И., Голиков В.В., Рылов Н.В. Испытание пневматической колонной флотомашины в операции углеродной флотации золотосодержащих руд Бакырчикского месторождения. Обогащение руд 2016. T. 3, С. 29-34 [Kovalev V.N., Asanova I.I., Golikov V.V., 
Rilov N.V. Pneumatic column flotation cells tests in the Bakyrchikskoye deposit gold bearing ores carbon flotation operation. Obogashchenie rud 2016. Vol. 3, P. 29-34 (in Russian)]

7. Bulatovic S.M. Handbook of flotation reagents. Oxford, 2010, Vol. 2, 219 p.

8. Александрова Т.Н., Цыплаков В.Н., Ромашев А.О., Семенихин Д.Н. Удаление сорбционноактивных углеродистых веществ из упорных золотосульфидных руд и концентратов месторождения Майское. Обогащение руд 2015. T. 4. C. 3-7 [Aleksandrova T.N., Tsiplakov V.N., Romashev A.O., Semenikhin D.N. Removal of sorption-active carboniferous components from difficultly-treated gold sulfide ores and concentrates of the Mayskoye deposi. Obogashchenie rud. 2015. Vol. 4. P. 3-7 (in Russian)] 